\title{
PENDIDIKAN KESEHATAN PENGENDALIAN FAKTOR RISIKO PENYAKIT KARDIOVASKULER, PENGETAHUAN DAN SIKAP REMAJA
}

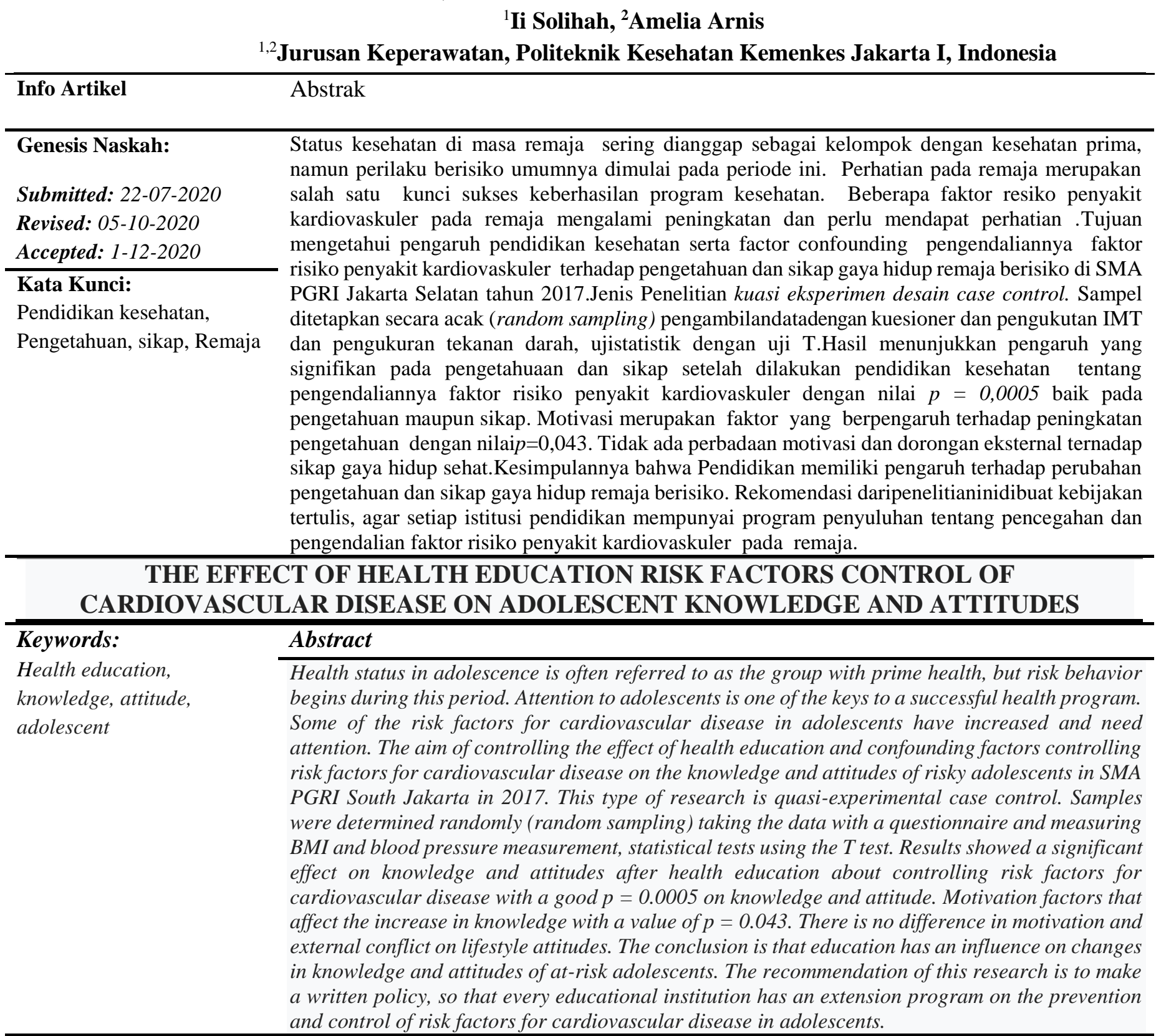

\section{Korespondensi Penulis:}

Ii Solihah

Jl. Wijaya Kusuma No. 47-48 Cilandak Jakarta Selatan

Email: ii_125@yahoo.com 


\section{Pendahuluan}

Masa remaja merupakan salah satu periode yang menentukan pola pembentukan status kesehatan di masa dewasa. Masa ini sering dianggap sebagai kelompok dengan kesehatan prima. Namun perilaku berisiko umumnya dimulai pada periode ini. Masa ini adalah periode transisi dari masa kanak-kanak menuju dewasa. Pola karakteristik pesatnya tumbuh kembang ini menyebabkan remaja memiliki rasa keingintahuan yang besar, menyukai petualangan dan tantangan serta cenderung berani mengambil resiko. Berbagai permasalahan yang terjadi pada remaja di pengaruhi oleh berbagai dimensi kehidupan dalam diri mereka, baik dimensi biologis, kognitif, moral dan psikologis serta pengaruh dari lingkungan sekitar (Soetjiningsih, 2004).

Pada dasarnya remaja menghadapi masalah kesehatan yang kompleks, walaupun selama ini diasumsikan sebagai kelompok yang sehat. Secara garis besar, masalah kesehatan remaja dapat dibagi ke dalam dua golongan yaitu masalah kesehatan fisik dan perilaku. Investasi yang sangat bermanfaat jika intervensi pencegahan faktor risiko penyakit kardiovaskuler dapat dilakukan saat ini (Soetjiningsih, 2004). Berdasarkan hasil survei diketahui besaran masalah kesehatan remaja terutama pada usia > 15 tahun, yang dimungkinkan menyebabkan faktor resiko penyakit kardiovaskuler yang terus mengalami peningkatan saat ini antara lain, yaitu merokok $36,3 \%$., obesitas untuk wilayah Jakarta Selatan sebesar 8,7 \%, Diabetes militus 2,1\%, kolesterol total abnormal 3,5\%, hipertensi bahkan mencapai 15\% (Kusmana, 1997), sementara data WHO menyatakan hampir dua pertiga kematian disebabkan oleh penyakit tidak menular dan membunuh penduduk dengan usia yang lebih muda (Balitbang Kemenkes RI, 2013).

Berdasarkan hasil penelitian lain pada 300 responden siswa didapatkan prevalensi penyakit hipertensi pada siswa sebesar 107 responden $(35,7 \%)$. Aktifitas fisik yang buruk merupakan faktor risiko

(C) PoltekkesKemenkes Jakarta I

Jl. Wijaya Kusuma No. 47-48 Cilandak Jakarta Selatan, Indonesia email: jurnalquality@poltekkesjakarta1.ac.id paling dominan terjadi pada siswa yaitu sebesar 164 responden $(54,7 \%)$. Obesitas merupakan faktor risiko yang memiliki peluang tertinggi (6 kali) berhubungan dengan penyakit kardiovaskuler (hipertensi) pada siswa. Faktor risiko yang berhubungan dengan kejadian hipertensi pada siswa adalah obesitas $(\mathrm{p}=$ $0,000)$ dan inaktifitas fisik dengan $\mathrm{p}=0,002$ ((Kemenkes RI, 2012). Hasil penelitian lain yang sesuai judul ini menunjukkan bahwa ada pengaruh pendidikan kesehatan terhadap perbedaan nilai pretest dan post-test pengetahuan $(\mathrm{p}=0,000)$ dan sikap $(\mathrm{p}=0,000)$ pada kelompok eksperimen (Nurhidayat, 2012), sementara data hasil survailen (pengawasan berkala) pada Penyakit Tidak Menular (PTM) di seluruh SMA baik Negeri atau swasta di wilayah kerja Puskesmas Kelurahan Pondok Labu di dapat data kecenderungan siwanya mengalami berat badan lebih.

Besarnya gambaran masalah tersebut, maka kesehatan remaja perlu mendapatkan perhatian terutama dalam pengendalian faktor risiko, melalui komunikasi, informasi dan edukasi yang tepat dan berbasis masyarakat (Wijoreni, 2014). Adapun tujuan penelitian ini adalah diketahuinya pengaruh pendidikan kesehatan tentang pengendaliannya faktor risiko penyakit kardiovaskuler terhadap pengetahuan dan sikap gaya hidup remaja berisiko.

\section{Metode}

Penelitian ini merupakan quasi eksperimen, dengan pre-post-test with control group design,dilaksanakan di SMA PGRI Pondok Labu Jakarta Selatan tahun 2017. Populasi penelitian seluruh siswa kelas XI. Sampel penelitian diambil dengan teknik purposive sampling dengan kriteria inklusi responden memiliki salah satu atau lebih faktor risiko penyakit kardiovaskuler yaitu IMT dengan katagori Kegemukan atau obesitas,tekanan darah dengan katagori prahiperensi atau hipertensi, memiliki kebiasaan merokok,atau memiliki salah satu atau lebih riwayat keluargadengan hipertensi, penyakit gula, penyakit jantung dan stroke. Instrumen yang digunakan dikembangkan oleh tim peneliti dengan modifikasi instrument baku, dengan output

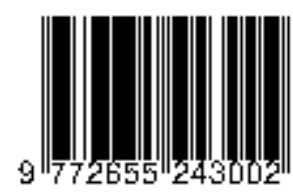


diketahui $\mathrm{r}$ hitung masing masing lebih dari 0,3 , namununtuk pertanyaan motivasi $r$ hitung lebih besar dari 0,3 dan angka cronbach alpa sebesar 0,768, angka ini menunjukkan reliable karena lebih dari nilai minimal yaitu $(0,6)$.Populasi berjumlah 138 setelah dilakukan pengukuran terdapat 63 responden yang memenuhi criteria, namun yang 3 orang dropout. Jumlah sampel masingmasing 30 orang per kelompok intervensi dan kontrol. Variabel independen pada penelitian ini adalah motivasi dan dukungan eksternal. Penyuluhan pada kelompok kasus dilakukan berupa paparan sedangkan pada kelompok kontrol diberikan leaflet. Pengumpulan data dilakukan dengan melakukan pengukuran tinggi badan, berat badan kemudian dikatagorikan menurut standar Antropometri penilaian status gizi anak (Kemenkes RI, 2012), mengukur tekanan darah serta kuesoner untuk pengetahuan dan sikap dalam melakukan pencegahan. Analisis menggunakan uji T, selanjutnya analisis multivariat dengan Anova pada variabel motivasi dan dukungan eksternal(keluarga dan teman).

\section{Hasil}

Hasil analisis didapatkan beberapa hal yang akan di sajikan dalam bentuk tabel, sebagai berikut:

Tabel 1. Distribusi Frekuensi Responden Menurut Faktor Risiko Peyakit Kardiovaskuler

\begin{tabular}{llcc}
\hline Variabel & Variabel & Frequency & $\begin{array}{l}\text { Percent } \\
(\%)\end{array}$ \\
\hline Jenis & Laki- laki & 35 & 58 \\
Kelamin & Perempuan & 25 & 42 \\
IMT & Gemuk & 59 & 98 \\
& Obesitas & 1 & 2 \\
Tekanan & Pra & 34 & 56 \\
darah & Hipertensi & 0 & \\
& Hipertensi & & \\
Merokok & Ya & 13 & 21 \\
Riwayat & Peny.Jantung & 12 & 20 \\
keluarga & Hipertensi & 15 & 25 \\
& DM & 16 & 26 \\
\hline
\end{tabular}

Tabel 1. menunjukkan proporsi jenis kelamin sebagian besar $(63,3 \%)$ responden berjenis kelamin laki-laki, dan sebagiian besar $59(98 \%)$ responden

(C) PoltekkesKemenkes Jakarta I

Jl. Wijaya Kusuma No. 47-48 Cilandak Jakarta Selatan, Indonesia email: jurnalquality@poltekkesjakarta1.ac.id memiliki IMT dengan katagori gemuk, sebagian besar $34(56 \%)$ responden megalami pra-hipertensi, terdapat $13(21 \%)$ responden memiliki kebiasaan merokok, dan responden memiliki riwayat keluarga dengan penyakit jantung 12 (20\%);15(25\%) hipertensi; serta $16(26 \%)$ memiliki riwayat keluargadengan Diabetes Militus.

Tabel 2.Distribusi Frekuensi Responden Menurut factor confounding Motivasi dan Dukungan Eksternal $n=60$

\section{VariabeL} Frequency Percent (\%)

\begin{tabular}{lcc}
\hline Motivasi & 27 & 45 \\
Baik & 33 & 55 \\
Cukup & - & - \\
Kurang & & \\
Dukungan Eksternal & 33 & 55 \\
Baik & 27 & 45 \\
Cukup & - & - \\
Kurang & & \\
\hline
\end{tabular}

Tabel 2. Menunjukkan proporsi motivasi sebagian besar 33 (55\%) Responden memiliki motivasi yang cukup dan sebagian besar $55(55 \%)$ responden memiliki dukungan eksternal yang baik.

Tabel 3. Distribusi Rata-Rata Pengetahuan dan Sikap terhadap Pengendalian Faktor Resiko Penyakit Kardiovaskuler menurut PengukuranI dan II pada Kelompok Intervensi dan Kontrol

\begin{tabular}{|c|c|c|c|c|c|c|}
\hline \multirow[b]{2}{*}{ Variabel } & \multicolumn{3}{|c|}{$\begin{array}{l}\text { Intervensi } \\
\text { Penkes }(\mathbf{n}=30\end{array}$} & \multicolumn{3}{|c|}{ Kontrol $(n=30)$} \\
\hline & SD & SE & $\begin{array}{l}P \\
\text { value }\end{array}$ & SD & SE & $\begin{array}{l}P \\
\text { value }\end{array}$ \\
\hline Tahu Pre & 8.9 & 1.6 & 0.0005 & 18.9 & 3.4 & $\begin{array}{c}0.000 \\
5\end{array}$ \\
\hline Гahu post & 5.3 & 0.9 & & 7.8 & 1.4 & \\
\hline Sikap Pre & 10.7 & 1.9 & 0.0005 & 7.9 & 1.4 & \\
\hline $\begin{array}{l}\text { Sikap } \\
\text { st }\end{array}$ & 7.0 & 1.2 & & 3.7 & 0.6 & $\begin{array}{c}0.000 \\
5\end{array}$ \\
\hline
\end{tabular}

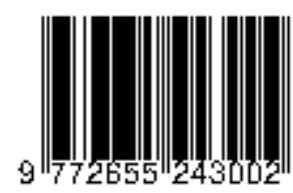


Tabel 3 menunjukkan pada kasus intervensi terdapat perbedaan antara pengukuran pengetahuan dan sikap pertama adalah 11,2 dan 14,00 dengan standar deviasi pengetahuan dan sikap masing-masing adalah 9,04 dan $-10,15$. Hasil uji statistic didapatkan nilai $p$ pengetahuan $=0,0005$ dan nilai $p$ sikap $=0,0005$, maka dapat disimpulkan ada perbedaan yang signifikan antara pengetahuan dan sikap pada pengukuran pertama dan kedua. Dan begitu pula hasil uji statistik pada kasus kontrol ada perbedaan yang signifikan antara pengetahuan dan sikap pada pengukuran pertama dan kedua.

Tabel 4. Distribusi rata rata pengetahuan pada faktor risiko penyakit kardiovaskuler menurut Motivasi dan dukungan eksternal

\begin{tabular}{|c|c|c|c|c|c|c|}
\hline \multirow[t]{2}{*}{ variabel } & \multicolumn{3}{|c|}{$\begin{array}{c}\text { Pengetahuan } \\
\text { Intervensi }(\mathrm{n}=30)\end{array}$} & \multicolumn{3}{|c|}{$\begin{array}{l}\text { Kontrol } \\
(\mathrm{n}=30)\end{array}$} \\
\hline & $\bar{X}$ & $95 \% \mathrm{CI}$ & $\begin{array}{c}P \\
\text { val } \\
\text { ue }\end{array}$ & $\begin{array}{l}- \\
X\end{array}$ & $95 \% \mathrm{CI}$ & $\begin{array}{l}P \\
\text { val } \\
\text { ue }\end{array}$ \\
\hline
\end{tabular}

\begin{tabular}{|c|c|c|c|c|c|c|}
\hline \\
\hline \multicolumn{7}{|l|}{ Baik } \\
\hline & & 99,8 & 0.043 & & $85,3-97,7$ & 0.60 \\
\hline Jukup & 92.8 & $\begin{array}{c}86,8- \\
89,7\end{array}$ & & 91,5 & & 75 \\
\hline $\begin{array}{l}\text { Dukungeks } \\
\mathrm{t}\end{array}$ & & & & & $\begin{array}{l}188,8-95,7 \\
86,6-93,5\end{array}$ & \\
\hline Baik & 96.7 & $94,5-$ & & 92.2 & & 0.78 \\
\hline Cukup & 96,9 & $\begin{array}{c}98,9 \\
92,0- \\
101\end{array}$ & 0.925 & 93.1 & & $\begin{array}{c}0.10 \\
4\end{array}$ \\
\hline
\end{tabular}

Tabel.4 Hasil uji statistic didapat nilai $\mathrm{p}<0,05$. berarti pada $\alpha 5 \%$ dapat disimpulkan ada perbedaan pengetahuan responden yang memiliki motivasi yang baik dan cukup, setelah dilakukan pendidikan kesehatan. Analisis ini membuktikan bahwa perbedaan motivasi dan dorongan eksternal memiliki perbedaan yang signifikan.

(C) PoltekkesKemenkes Jakarta I

J1. Wijaya Kusuma No. 47-48 Cilandak Jakarta Selatan, Indonesia email: jurnalquality@poltekkesjakarta1.ac.id
Tabel 5. Distribusi Rata-Rata Sikap pada Faktor Resiko Penyakit Kardiovaskuler Menurut Motivasi dan Dukungan Eksternal

\begin{tabular}{|c|c|c|c|c|c|c|}
\hline \multirow[t]{2}{*}{ variabel } & \multicolumn{3}{|c|}{$\begin{array}{c}\text { Sikapintervensi } \\
\qquad \mathbf{n}=\mathbf{3 0}\end{array}$} & \multicolumn{3}{|c|}{$\begin{array}{c}\text { Sikap control } \\
\mathbf{n}=\mathbf{3 0}\end{array}$} \\
\hline & $x^{-}$ & $\begin{array}{c}95 \% \\
\text { CI }\end{array}$ & $\begin{array}{r}\mathrm{P} \\
\text { Val } \\
\text { ue }\end{array}$ & $\begin{array}{l}- \\
X\end{array}$ & $\begin{array}{l}95 \% \\
\text { CI }\end{array}$ & $\begin{array}{c}\text { P } \\
\text { Val } \\
\text { ue }\end{array}$ \\
\hline $\begin{array}{l}\text { Motivsi } \\
\text { Baik }\end{array}$ & 75.0 & $\begin{array}{l}70,3- \\
79,3\end{array}$ & $\begin{array}{r}0.6 \\
49\end{array}$ & 90,0 & $\begin{array}{l}88,5- \\
91,4\end{array}$ & $\begin{array}{l}0.9 \\
025\end{array}$ \\
\hline Cukup & 77.3 & $\begin{array}{l}66.7- \\
87,9\end{array}$ & & 89,8 & $\begin{array}{l}86,3- \\
93,2\end{array}$ & \\
\hline $\begin{array}{l}\text { Dukungan } \\
\text { Eksterna }\end{array}$ & & & & & & \\
\hline Baik & 75,5 & $\begin{array}{l}70,8- \\
80,1\end{array}$ & $\begin{array}{r}1.0 \\
0 .\end{array}$ & 89,6 & $\begin{array}{l}88,1- \\
91,1\end{array}$ & $\begin{array}{l}0.5 \\
72\end{array}$ \\
\hline Cukup & 75,5 & $\begin{array}{l}66.3- \\
84,6\end{array}$ & & 90,5 & $\begin{array}{l}87,0- \\
93,9\end{array}$ & \\
\hline
\end{tabular}

Hasil uji statistic didapat nilai $\mathrm{p}>0,05$. Analisis ini membuktikan bahwa tidak ada perbadaan motivasi dan dorongan eksternal terhadap sikap gaya hidup sehat.

\section{Pembahasan}

Berdasarkan hasil menunjukkan bahwa motivasi bergaya hidup sehat dengan katagori cukup merupakan yang terbanyak $33(55 \%)$ dibanding yang memiliki motivasi yang baik $27(45 \%)$, sementara hasil analisis menunjukkan bahwa motivasi memiliki pengaruh terhadap pengetahuan responden. Hasil ini sesuai dengan penelitian yang menyatakan, bahwa motivasi merupakan faktor yang berhubungan dengan kemampuan pasien PJK dalam melakukan pencegahan sekunder terhadap faktor risiko $\mathrm{p}=0,003$ (Indrawati L, 2012)., sama halnya dengan penelitian $^{8}$, bahwa terdapat hubungan yang sigifikan antara pendidikan kesehatan terhadap pengetahuan dan sikap sebelum dan sesudah dilakukan pendidikan 
kesehatan tentang bahaya rokok dengan nilai $\mathrm{p}=$ 0,000 .

Hasil analisis bivariate menunjukkan bahwa dukungan eksternal tidak memiliki pengaruh terhadap pengetahuan responden. Berbeda halnya dengan penelitian lain yang menyatakan bahwa penyampaian pendidikan kesehatan oleh peer group berpengaruh terhadap peningkatan pengetahuan remaja $\mathrm{p}=0,000$ (Suriani, 2014), sejalan dengan sebuah penelitian yang menyatakan bahwa dukungan sosial dari teman merupakan yang paling berpengaruh terhadap subjective well-being remaja $\mathrm{p}=0,000$ dan $\mathrm{R}=0,440$ (Kumalasari F, 2012).

Pengaruh motivasi terhadap sikap dari hasi uji statistic tidak ada pengaruh. Sementara penelitian lain menyatakan, bahwa ada pengaruh yang signifikan antara motivasi dan sikap baik sebelum dan sesudah diberikan Pendidikan Kesehatan tentang hipertensi $\mathrm{p}=0,000$ (Susanti MT, 2013), sama halnya dengan sebuah hasil penelitian yang menyatakan bahwa motivasi merupakan faktor yang paling dominan terhadap kemampuan pasien PJK dalam melakukan pencegahan sekunder terhadap factor risiko $p=0,0001$ (Indrawati $\mathbf{L}, \mathbf{2 0 1 2}$ ).

Motivasi merupakan usaha yang dilakukkan sehingga seseorang memiliki kemauan yang berasal dari dalam diri (Kumalasari F, 2012). Motivasi belajar menurut Rizqi, Annisa Afianda, (2018) adalah factor keluarga dan factor sekolah. Hasil penelitian lain menyebutkan, adanya korelasi motivasi dengan dua komponen (Rizqi AA, 2018). Perhitungan component transformation matrix menunjukkkan bahwa pada komponen 1 nilai korelasinya sebesar 0,749>0,5 dan komponen 2 nilai korelasinya sebesar $0,749>0,5$. Komponen 1 adalah cita-cita/aspirasi siswa, kondisi lingkungan, dan unsur-unsur dinamis dalam belajar dan pembelajaran dan komponen 2 adalah kondisi siswa, upaya guru dalam mengelola kelas, dan kemampuan siswa (Moslem MC, 2013).

Pengaruh yang banyak mempenngaruhi motivasi belajar benayak dari eksternal siswa. Pengaruh dukungan eksternal terhadap sikap dari hasil uji statistic tidak ada pengaruh, sementara

(C) PoltekkesKemenkes Jakarta I

J1. Wijaya Kusuma No. 47-48 Cilandak Jakarta Selatan, Indonesia email: jurnalquality@poltekkesjakarta1.ac.id penelitian lain menyatakan, bahwa ada hubungan antara dukungan social dengan penyesuaian diri remaja di panti asuhan $\mathrm{p}=0,011$ (Kumalasari $\mathbf{F}$, 2012). Dukungan ekstrinsik dapat berasal dari sekolah. Menurut Musab, I, \& Witri, G. (2019), factor yang paling berpengaruh terhadap motivasi belajar adalah disiplin sekolah yaitu sebesar 11,22\% dari 149 responden (Musab I, 2019).

\section{Kesimpulan dan Saran}

1. Mayoritas responden memiliki IMT dengan katagori gemuk dan mengalami pra-hipertensi, kurang dari separuh memiliki kebiasaan merokok, dan Sebagian kecil responden memiliki riwayat keluarga dengan penyakit jantung hipertensi dan Diabetes Melitus.

2. Sebagian besar responden memiliki motivasi yang cukup dan memiliki dukungan eksternal yang baik dalam mencegah faktor risiko penyakit kardiovaskuler.

3. Terdapat pengaruh yang signifikan pada pengetahuan dan sikap setelah dilakukan pendidikan kesehatan tentang faktor risiko penyakit kardiovaskuler dan pengendaliannya.

4. Motivasi merupakan faktor yang berpengaruh terhadap peningkatan pengetahuan tentang faktor risiko penyakit kardiovaskuler

Penelitian ini bisa dijadikan dasar dalam megetahui tentang pengetahuan dan sikap yang yang lebih mendalam dengan berban merbagai metode lainnya dan diharapkan dapat menjadi pertimbangan bagi setiap instansi kesehatan untuk membuat kebijakan tertulis tentang pelaksanaan penyuluhan pengenalan dan pengendalian Penyakit Kardiovaskuler pada Remaja di institusi pendidikan.

Daftar Pustaka

Balitbang Kemenkes RI. Riset Kesehatan Dasar [Internet]. Jakarta; 2013. Tersedia pada: http://kesga.kemkes.go.id/images/pedoman/Dat a Riskesdas 2013.pdf

Indrawati L. Analisis Faktor yang Berhubungan dengan Kemampuan Pasien Melakukan Pencegahan Sekunder Faktor Risiko di RSPAD Gatot Soebroto Jakarta [Internet]. Universitas Indonesia; 2012. Tersedia pada:

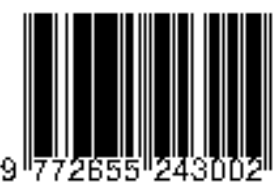


http://lib.ui.ac.id/file?file=digital/20313795-T

31743-Analisis faktor-full text.pdf

Kemenkes RI. Penyakit Tidak Menular. Buletin Jendela Data dan Informasi Kesehatan [Internet]. 2012; Tersedia pada: https://pusdatin.kemkes.go.id/article/view/1301 $\underline{0200029 / \text { penyakit-tidak-menular.html }}$

Kumalasari F, Pengajar S, Psikologi F. Hubungan antara Dukungan Sosial dengan Penyesuaian Diri Remaja di Panti Asuhan Latifah Nur Ahyani. 2012;1(1). Tersedia pada: https://jurnal.umk.ac.id/index.php/PSI/article/vi ew/33/32

Kusmana. Olah Raga bagi Kesehatan Jantung [Internet]. Jakarta: FKUI; 1997. Tersedia pada: https://onesearch.id/Record/IOS2888.JATEN00 0000080001017

Moslem MC, Komaro M, Yayat A. Faktor-Faktor yang Menyebabkan Rendahnya Motivasi Belajar Siswa dalam Mata Pelajaran Aircraft Drawing di SMK. J Mech Eng Educ. 2019;6

Musab I, Witri G. Faktor Ekstrinsik yang Mempengaruhi Motivasi Belajar Siswa Kelas IV Sekolah Dasar Se-Gugus 2 Kecamatan Sail Pekanbaru. J Pendidik Guru Sekol Dasar. 2019

Nurhidayat. Persepsi Siswa SMP Putra Bangsa terhadap Perilaku Merokok di Kelurahan Kemiri Muka, Depok [Internet]. 2012. Tersedia pada: http://lib.ui.ac.id/file?file=digital/20309050-S 43125-Persepsi siswa-full text.pdf

Puryanto, Juni E, Santoso. Pengaruh Pendidikan Kesehatan terhadap Pengetahuan dan Sikap Siswa tentang Bahaya Rokok. Karya Ilm S 1 Ilmu Keperawatan [Internet]. 2012; Tersedia pada:

http://ejournal.stikestelogorejo.ac.id/index.php/i lmukeperawatan/article/view/71/106

Rizqi AA, Yusmansyah Y, Mayasari S. Faktor yang Mempengaruhi Motivasi Belajar. FKIP Univ Lampung. 2018

(C) PoltekkesKemenkes Jakarta I

Jl. Wijaya Kusuma No. 47-48 Cilandak Jakarta Selatan, Indonesia email: jurnalquality@poltekkesjakarta1.ac.id
Soetjiningsih. Buku Ajar: Tumbuh Kembang Remaja dan Permasalahannya. Jakarta: Sagung Seto; 2004

Suriani, Hermansyah. Pengaruh Peer Group terhadap Peningkatan Pengetahuan Kesehatan Reproduksi Remaja. J Ilmu Keperawatan [Internet]. 2014;23-9. Tersedia pada: http://jurnal.unsyiah.ac.id/JIK/article/view/518 $\underline{6 / 4352}$

Susanti MT, Suryani M, Shobirun. Pengaruh Pendidikan Kesehatan tentang Hipertensi terhadap Pengetahuan dan Sikap Mengelola Hipertensi di Puskesmas Pandanaran Semarang. 2013; Tersedia pada: http://ejournal.stikestelogorejo.ac.id/index.php/i lmukeperawatan/article/view/66/105

Wijoreni. Hidup Sehat Terhadap Tingkat Pengetahuan Dan Sikap Dalam Mencegah Penyakit Tidak Menular [Internet]. Surakarta; 2014. Tersedia pada: http://eprints.ums.ac.id/31157/ 